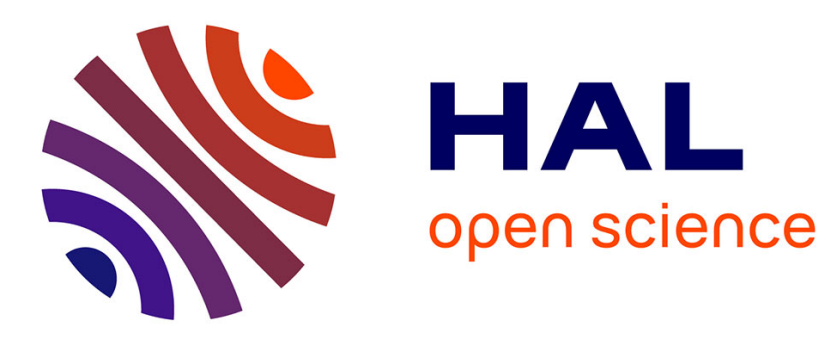

\title{
Why do continents break-up parallel to ancient orogenic belts?
}

\author{
A Vauchez, Guilhem Barruol, Andrea Tommasi
}

\section{To cite this version:}

A Vauchez, Guilhem Barruol, Andrea Tommasi. Why do continents break-up parallel to ancient orogenic belts?. Terra Nova, 1997, 9, pp.62 - 66. 10.1111/j.1365-3121.1997.tb00003.x . hal-01389721

\section{HAL Id: hal-01389721 \\ https://hal.univ-reunion.fr/hal-01389721}

Submitted on 29 Oct 2016

HAL is a multi-disciplinary open access archive for the deposit and dissemination of scientific research documents, whether they are published or not. The documents may come from teaching and research institutions in France or abroad, or from public or private research centers.
L'archive ouverte pluridisciplinaire HAL, est destinée au dépôt et à la diffusion de documents scientifiques de niveau recherche, publiés ou non, émanant des établissements d'enseignement et de recherche français ou étrangers, des laboratoires publics ou privés. 


\title{
Why do continents break-up parallel to ancient orogenic belts?
}

\author{
A. Vauchez*, G. Barruol and A. Tommasi $\dagger$ \\ Laboratoire de Tectonophysique, Université de Montpellier II \& CNRS, F-35095 Montpellier Cedex 05, France
}

\begin{abstract}
The frequently observed parallelism between rifts and the preexisting orogenic fabric of continents suggests that the inherited tectonic fabric of the lithosphere influences the rupture of continents. We propose that the existence of a pervasive fabric in the lithospheric mantle induces an anisotropic strength in the lithosphere, that guides the propagation of continental rifts. Subcrustal mantle mechanical anisotropy is supported by (i) the anisotropic strength of olivine, (ii) an ubiquitous tectonic fabric in exposed mantle rocks, and (iii) measurements of seismic and electrical anisotropy. During major episodes of continent
\end{abstract}

assembly, a pervasive deformation of the lithosphere induces a lattice-preferred orientation of olivine in mantle rocks. Later on, this crystallographic fabric is 'frozen-in' and represents the main source of shear wave splitting. This olivine fabric may entail a mechanical anisotropy in the lithospheric mantle. During subsequent tectonic events, especially during rifting, mechanical anisotropy may control the tectonic behaviour of the lithosphere.

\section{Rifting parallel to orogenic belts}

Ocean-opening through rifting and continent break-up is frequently related to the occurrence of hotspots. There is, however, a discrepancy between hotspots acting as pinpoint sources of heat and the linear extent of rifts over thousands of kilometres. Moreover rifts tend to parallel pre-existing orogenic fabrics, e.g. North Atlantic rift (Wilson, 1966), Rio Grande rift (Olsen et al., 1987), North-east China rift (Ma and Wu, 1987), Baïkal rift (Delvaux et al., 1995), East African rift (Ring, 1994), West African rift (e.g. Fairhead and Binks, 1991), Cape Graben (Burke, 1976), and Eastern Brazilian rift (Chang et al., 1992). From these observations it was suggested that structural inheritance influences rift propagation. This paper propounds that the source of structural inheritance lies in the fabric of the lithospheric mantle developed during major orogenic episodes.

The East African rift and the North and South Atlantic oceans provide spectacular examples of parallelism between rifts and older orogenic belts. The East African rift system (Fig. 1), $>2000 \mathrm{~km}$ long and still active, formed mostly during the Cenozoic in a shield stable since the Neoproterozoic (Ring, 1994). The southern part of the system trends almost N-S, parallel to the Mozambique belt. Northward, the rift system splits into two branches that wrap around the Tanzania craton. The eastern branch remains parallel to the

Correspondence: A. Vauchez, E-mail: vauchez@dstu.univ-montp2 fr

talso at Lab. Petrologie et Tectonique. Université Lyon I \& CNRS, France
Mozambique belt and terminates northward into the Afar. The western branch follows the Ubendian belt that curves from NW-SE to NE-SW. Theunissen et al. (1996) showed that: (i) the Ubendian belt, south and west of the Tanzania craton, is a wide and steep shear belt resulting from Palaeo- and Neoproterozoic tectonic events, (ii) the west Tanzania rift developed during Phanerozoic times through multiphase reactivation of the Precambrian steeply dipping fabric, and (iii) fault geometry and kinematics are complex and point toward a SE-NW propagation of the rift in a dextral transtensional strain regime.

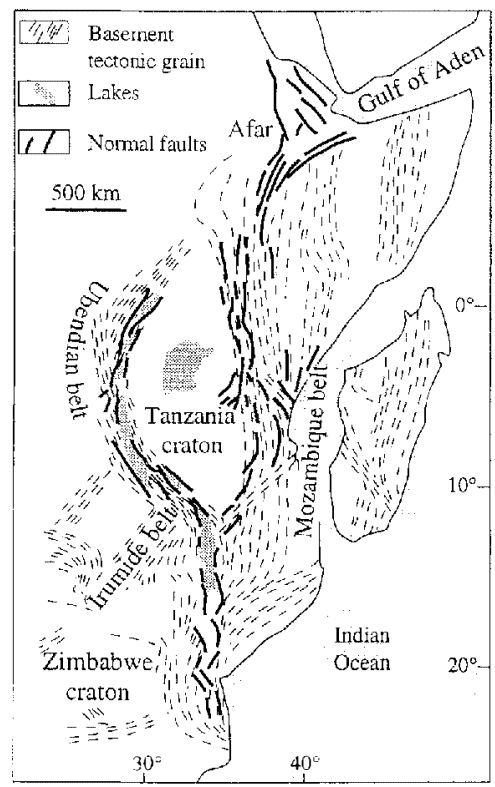

Fig. 1 Schematic map (modified from Ring, 1994) illustrating the parallelism between normal faults in the East African Rift and basement structural fabric.
From Florida to the Barents Sea, the North Atlantic ocean opening occurred parallel to the Hercynian and Caledonian orogens (Fig. 2). In eastern North America, parallelism between the Appalachians, Triassic rifts, the continent margin, and the main magnetic anomalies that mark the Atlantic opening indicates that the initial rift propagated along the internal domain of the belt. South of the West African craton, the Atlantic rift formed parallel to Neoproterozoic (southern Senegal, Sierra Leone) and Hercynian belts (nor thern Senegal, Mauritania). North of the craton, rifting at $\approx 200$ Ma reactivated the Hercynian belt of Morocco (Piqué and Laville, 1996). South of the North American continent. formation of oceanic lithosphere in the Gulf of Mexico was preceded by the development of triassic extensional basins elongated parallel to the Ouachitas mountains (Worral and Snelson, 1989).

Gondwana Cretaceous break-up between South America and Africa is

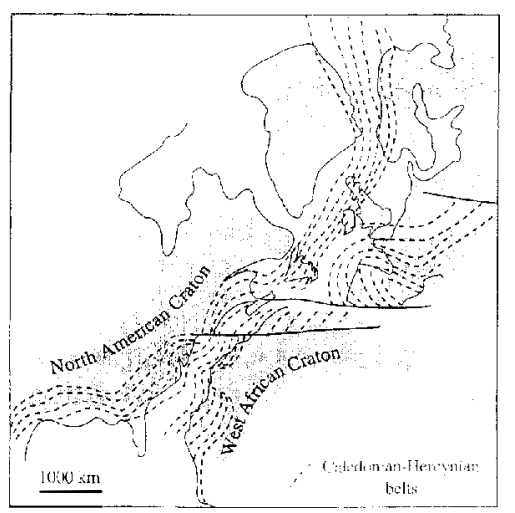

Fig. 2 Schematic map of circum-North Atlantic Caledonian-Hercynian belts beforc North Atlantic rifting. 
related to the upwelling of the Tristan da C.unha and St. Helena plumes. The initial rift system, however, propagated over more than $3000 \mathrm{~km}$ between and beyond these structures, following the Malmesbury-Gariep, Dom Feliciano, Kaoko, Ribeira and West Congolian Neoproterozoic belts (Fig. 3a). The parallelism observed between the South Atlantic rift system and the continental fabric is frequently striking since basins follow the curvatures of these orogenic belts. At the southern tip of Africa, for instance, the initial rift bends parallel to the Gariep-Malmesbury then the Cape fold belts where it became transtensional (Burke, 1976). Along the eastern coast of Brazil, Chang et al. (1992) showed that the east Brazilian rift is remarkably parallel to basement structures (Fig. 3b). Even where it propagated in the São Francisco craton, the south Atlantic rift followed the steep tectonic fabric and large-scale shear zones of the 2Gyr-old Itabuna belt and Salvador-Esplanada belt of unknown age. Burke (1976) emphasized that grabens oblique to the tectonic fabric of the continents rapidly aborted. The central Atlantic is more complex since the ocean curves from $\mathrm{N}-\mathrm{S}$ to almost $\mathrm{E}-\mathrm{W}$ and crosscuts various geotectonic domains. Bonatti (1996) suggests that a cold equatorial belt impeded the propagation of the southern Atlantic rift northward. An aborted branch of the rift propagated north of this cold

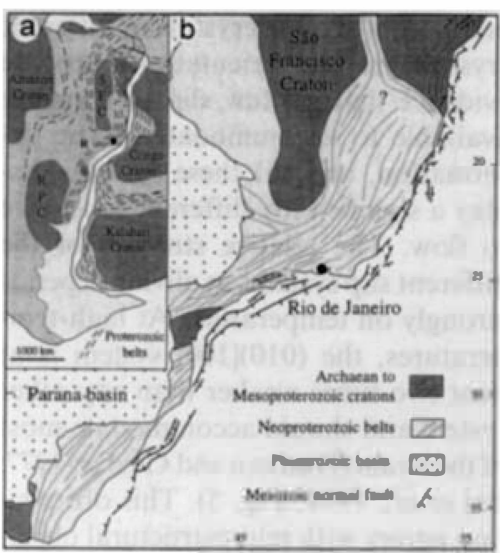

Fig. 3 Schematic map of circum-South Atlantic Neo-Proterozoic belts (insert) and of eastern Brazil showing the parallelism between the Neoproterozoic belts and the Cenozoic rifts formed along the continent margin. Normal faults from Chang et al. (1992). SFC, São Francisco craton; RPC, Rio de la Plata craton; R, Ribeira belt. belt along the $\mathrm{N}$-S-trending Neoproterozoic Dahomeyide belt, but the main continental breakup occurred through wrench faulting between the St. Helena plume and the North Atlantic spreading ridge. This Cretaceous wrench tectonics (Fairhead and Binks, 1991) reactivated Neoproterozoic transcontinental E-W-shear zones.

\section{Rift propagation and rheological heterogeneity of the continental lithosphere}

Various interpretations have been proposed to explain the relationship between continental lithospheric rifts and the tectonic fabric of continents. Rheological calculations (e.g. Dunbar and Sawyer, 1989) show that an increase in crustal thickness can halve the total strength of the continental lithosphere and thus favour localization of rifting. In active orogens, crustal thickness is expected to vary and to culminate close to suture zones that represent good candidates for the localization of subsequent rifting. For rifting beginning shortly after the end of an orogeny (e.g. North Atlantic in the Appalachians/ Mauritanides orogen), variation in crustal thickness across the belt is likely and may result in lateral variation of the total strength of the lithosphere and favour the localization of the rupture process.

Local lithospheric weakness associated with crustal roots does not satisfactorily explain rift propagation within an old and stable shield (e.g. South Atlantic or East African rifts). The time lag between the last orogeny and rift initiation is of several hundreds of Myr, a duration long enough for large-scale excess crustal thickness to be removed by surface erosion, isostatic compensation or gravitational collapse. The gravity map of Brazil, for instance, does not show any anomaly suggesting a residual crustal root beneath late Proterozoic orogens (Ussami et al., 1993), and it may reasonably be assumed that this was already the case during the Cretaceous when the South Atlantic rifting initiated.

Rheological heterogeneity of the continental lithosphere may also arise from old cratonic nuclei incorporated into continents (e.g. Tommasi et al., 1995). Even several hundreds of Myr after continent assembly, old cratonic nuclei display a 'colder' geotherm and a thicker lithosphere than the surrounding terranes. Their stiffer lithosphere tends to impede propagation of rifts into cratonic nuclei, and their boundary with the surrounding lithosphere may represent a preferential site for extensional deformation to localize. This model is certainly valid for rifts formed along old cratonic nuclei as the Baïkal and the Kenya rifts, although it remains difficult to evaluate the respective contribution of rheological heterogeneity and structural inheritance since usually orogenic belts wrap around the cratons and rifts are parallel to both the craton boundary and the surrounding belts. Moreover, rheological heterogeneities fail to explain all cases of rifts developed in an ancient continental lithospherc, since in many places rifts formed far from any old cratonic nucleus (e.g. the southern East African Rift or the South Atlantic rift).

\section{Inherited lithospheric mantle fabric: clues from seismic and electrical anisotropies}

Upper mantle xenoliths and peridotite massifs usually display a well-defined crystallographic fabric due to past deformation of the lithosphere (e.g. Mercier and Nicolas, 1975). Since upper mantle rock-forming minerals (especially olivine) are seismically anisotropic, their crystallographic preferred orientation results in a significant seismic anisotropy of mantle rocks (e.g. Nicolas and Christensen, 1987), and is regarded as the main source of teleseismic shear wave splitting (Silver, 1996). This supports the notion that shear wave splitting is mostly related to the tectonic fabric of the upper mantle, either duc to active (asthenospheric) or 'frozen' (lithospheric) mantle flow. Short-scale spatial variations of splitting parameters on continents and a good correlation with surface geology (e.g. Barruol et al., 1997) point to a dominant contribution of continental lithospheric mantle fabric to the splitting of shear waves.

Most commonly, the fast split shear wave is polarized subparallel to the tectonic grain of the orogens (e.g. Silver, 1996). The difference in arrival time between the fast and slow waves is usually around $1 \mathrm{~s}$ and may exceptionally exceed $2 \mathrm{~s}$. Considering the intrinsic anisotropy of mantle xenoliths, such time lags require that the waves propagated through at least a $100 \mathrm{~km}$-thick layer of anisotropic man- 
tle characterized by a preferred orientation of the [010] and [100] axes of olivine. respectively, perpendicular and close to the strike of the belt (Mainprice and Silver, 1993). These measurements hint at the existence of a well-developed crystallographic fabric over the entire thickness of the lithospheric mantle.

Coupled shear wave splitting and magnetotelluric experiments tend to support a common lithospheric origin of seismic and electrical anisotropies. Electrical conductivity anisotropy is often interpreted as resulting from the existence of conducting graphite films along grain boundaries, with the highest conductivity parallel to the foliation trend (e.g. Sénéchal et al., 1996). The depth at which electrical anisotropy occurs is related to the frequency range in which it is observed, and is therefore approximately determinable. Sénéchal et al. (1996), for instance, carried out shear wave splitting measurements and magnetotelluric soundings along a transect in the Canadian shicld: consistent directions of anisotropy and measured electrical anisotropy originating between 50 and $150 \mathrm{~km}$, suggested that seismic anisotropy originated from a well-defined fabric in the lithospheric upper mantle. Preliminary results from a magnetotelluric experiments in the eastern US (Ogawa et al., 1996) also point to a subcrustal electrical anisotropy with the highest conductivity along the strike of the Appalachians, a result consistent with shear wave splitting data.

Shear wave splitting measurements in the Appalachians (Barruol et al., 1997) and the Pyrenees (Barruol and Souriau, 1995) show (Fig. 4) that most stations located in the external tectonic domains, or even beyond the front of the belts, are characterized by fast split waves polarized parallel to the belts. This observation cannot be explained by a pervasive deformation of the lithosphere during the Appalachian or the Pyrenean orogenies only. since seismic reflection profiles across the Appalachians (Cook et al., 1979) and the Pyrenees (Choukroune, 1992) strongly suggest that deformation only affected the shallow crust of the cxternal domains of these belts. The most likely explanation is that the fabric of the lithospheric mantle responsible for shear wave splitting was not formed during the Appalachian or the Pyrenean orogenies, but was inherited from an earlier orogenic episode (Vauchez and Barruol, 1996). These two belts lie on the edge of continents that were mostly built during the Grenvillian orogeny for the eastern US and the Hercynian orogeny for the western Europe. Considering that, during these episodes of continent assembly, strips of continental lithosphere $>1000 \mathrm{~km}$ wide were deeply deformed, it may be expected that a pervasive fabric was developed over the entire lithosphere.

Inherited lithospheric fabric had a clear influence on the evolution of eastern North America. The NE-trending Appalachian belt and EW-trending Ouachitas Mountains are consistently parallel with the Grenville belt. In its Canadian branch, the main thrust faults and limits of tectono-metamorphic zones of the Grenville belt trend northeastward (Hoffman, 1989). Southward, exposures are scarce, but magnetic and gravimetric anomalies characteristic of the belt domains allow identification of buried terranes and of their limits. PostGrenvillian structures systematically formed parallel to the Grenville belt. In the Upper Proterozoic-Lower Palaeozoic (i.e. about $400 \mathrm{Myr}$ after the Grenville orogeny), the lithosphere was rifted parallel to the belt, then a passive margin formed. After a period of ocean opening. the eastern American margin turned convergent, underwent oblique accretion of terranes and finally collision with Africa, resulting in the building of the Appalachian-Ouachitas system that fits almost exactly the Grenville belt. Then a similar cvolution recurred (Wilson, 1966) with the opening of the North Atlantic ocean along the Appalachian internal domain.

Reconstitution of the Variscan belt also highlights parallelism between the Pyrenees and pre-existing Hercynian structures. The tectonic fabric of the Pyrenees axial zone is mostly Hercynian in age, and parallels the belt (e.g. Zwart, 1986). This led us to suggest that the roughly $\mathbf{E}-\mathbf{W}$ fast polarization directions found in the southern Pyrenees (Fig. 4) may be generated by an inheritcd Hercynian lithospheric fabric (Barruol and Souriau, 1995; Vauchez and Barruol, 1996). A strong mechanical effect of this inherited fabric is suggested from the subsequent geodynamic evolution of the pyrenean domain. Iberia displacement relative to Eurasia along the North Pyrenean Fault (NPF) started when the Atlantic rift, following the curvature of the Hercynian belt, wrapped around Iberia and produced the opening of the bay of Biscay. This triggered the break-up between Europe and Iberia, with the initial rupture occurring parallel to the Hercynian belt in the future site of the Pyrenees. Subsequently. pull-apart basins elongated parallel to the plate boundary formed $\approx 100 \mathrm{Ma}$ north of the NPF. Finally, N-S convergence of Iberia and Europa. mainly during the Eocene, led to the formation of the Pyrenees which also parallels the older hercynian grain.

\section{Mechanical anisotropy of the lithospheric mantle}

The existence of a penetrative fabric within the lithospheric mantle suggests an alternative explanation for continental break-up parallel to orogenic belts. If the strength of individual crystals in mantle rocks is anisotropic, a strong. lattice-preferred orientation of rockforming minerals may entail a mechanical anisotropy of upper mantle rocks and therefore of the lithosphere.

Metals, ceramics or ice often display a mechanical anisotropy, i.e. their strength aepends on the orientation of the applied force. Rocks may also display such a mechanical anisotropy (e.g. Siricys. 1982): under tension. their strength is generally lower for extension normal than parallel to the foliation plane. This bchaviour is especially clear during elastic and brittle deformation, but it also occurs during ductile deformation.

Microscopic studies of deformed peridotites and experimental axial compression of olivine crystals in different crystallographic orientations provide evidence that: (i) few slip systems are available to accommodate plastic deformation, and (ii) these systems display a significantly different resistance to flow. The relative strength of the different slip systems in olivine depends strongly on temperature. At high-temperatures, the $(010)[100]$ system is at least two times weaker than any other system and should accommodate most of the strain (Durham and Goctze, 1977 : Bai et al., 1991; Fig. 5). This observation agrees with microstructural observations of naturally deformed peridotites (e.g. Nicolas and Poirier, 1976), which clearly indicate that olivine deforms predominantly by glide on the $(010)[100]$ slip system under upper mantle conditions. Under experimental conditions, a transition from this high temperature [100] glide to low-temperature [001] glide occurs at c. 1000 C. However, at nat- 

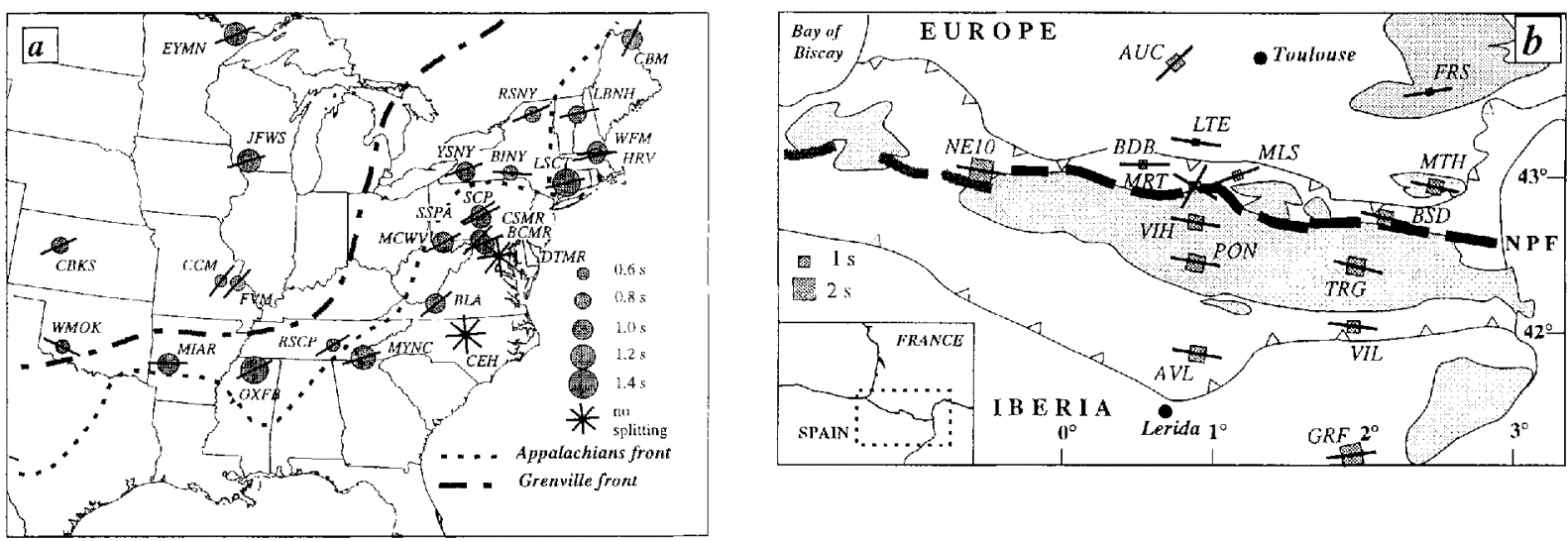

Fig. 4 Teleseismic shear wave splitting in (a) the Appalachians (Barruol et al.,1997) and (b) the Pyrenees. Anisotropy data in the Central Pyrenees from Barruol and Souriau (1995); in the Eastern Pyrenees the map shows preliminary results from a portable experiment by the Université de Montpellier II and the Observatoire Midi Pyrénées of Toulouse. Black lines show directions of fast split wave polarization; size of grey circles (a) or squares (b) are proportional to the time lag between fast and slow waves. Abbreviations are for station locations. Grey areas in (b) represent exposed Hercynian massifs.

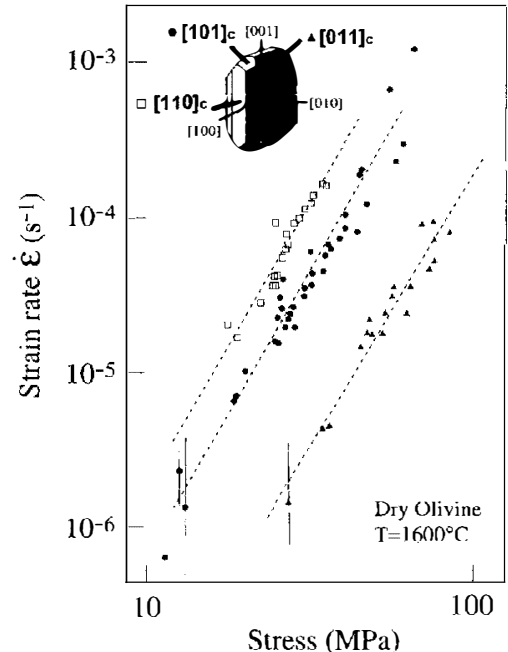

Fig. 5 Stress-strain rate plot for dry olivine single crystals compressed in three different directions $([110] \mathrm{c},[101] \mathrm{c},[011] \mathrm{c})$ relative to the crystallographic structure. (After Durham and Goetze, 1997.)

ural strain rates this transition occurs at lower temperatures. Thus we might expect that upper mantle rocks displaying a crystallographic preferred orientation of olivine will be mechanically anisotropic. Recent experimental axial compression of dunite under high temperature and pressure (Chopra, pers. comm. 1995; Wendt and Mainprice in prep.) confirm this hypothesis: the strength of pretextured dunites depends on the orientation of the foliation with the lowest strength and the most ductile behaviour for compression at $45^{\circ}$ to the foliation.

The mechanical behaviour of an aggregate displaying an initial lattice- preferred orientation may also be approached through a self-consistent numerical model (Lebensohn and Tomé, 1993); for a dunite, strength ratios larger than 2 are obtained depending on the orientation of the stresses relative to the crystallographic fabric. Thus if, as suggested from shear wave splitting measurements, the continental lithosphere is characterized by a steep foliation and a low-angle lineation, preferential orientation of the weak (010)[100] slip system should induce reactivation of the initial fabric involving a strike-slip component. This theoretical consideration is consistent with the large proportion of earthquakes with a significant component of strike-slip faulting that occur within continental rift zones (Doser and Yardwood, 1991).

\section{Conclusion}

Evidence from xenoliths and peridotite massifs, shear wave splitting and magnetotelluric soundings strongly support that the lithospheric mantle beneath continents retains a penetrative fabric developed during past orogenies. In the Pyrenees or the eastern US, seismic anisotropy studies together with the tectonic history of these continental domains suggest that break-up occurred preferentially along a mantle fabric formed during the Grenvillian or the Hercynian orogeny.

Considering that olivine crystals display a significant mechanical anisotropy, we suggest that after a main episode of continent assembly, the lithosphere displays a mechanical anisotropy due to a pervasive crystallographic/tectonic fabric. Anisotropic strength of the lithosphere may favour break-up of continents parallel to existing fabric even if the extension direction is not normal to the structural trend of the belt. In this latter case, rifting will be characterized by a transtensional deformation associating extension and strike-slip faulting.

Rifts tend to propagate where the energy required for lithosphere breakup is minimum. Because cratonic roots are stiffer than surrounding terranes, rifts will generally bypass these domains and localize in mobile belts around them. When rifting occurs rapidly after an orogenic crisis, the mechanical anisotropy of the mantle may be enhanced by thermal heterogeneities and lithosphere strength variation due to local crustal thickening. All these processes have convergent effects. Mechanical anisotropy, however, should be preserved as long as temperature conditions do not allow a significant modification (by annealing for instance) of the fabric of mantle rocks to occur; it may therefore satisfactorily account for the observed break-up of continents along their main structural trend several hundreds of Myr after the last orogeny.

\section{Acknowledgements}

This paper is a contribution to International Commission of the Lithosphere program III-5. We are indebted to A. Souriau who is co-owner of seismic data in the Eastern Pyrenees. We also thank D. Mainprice and R. Meissner for valuable discussions. 


\section{References}

Bai, Q., Mackwell, S.J. and Kohlstedt, D.L., 1991. High-temperature crecp of olivine single crystals. 1. Mechanical results for buffered samples. J. geophys. Res., 96. 2441-2463.

Barruol, G., Silver; P.G. and Vauchez, A., 1997. Seismic Anisotropy In The Eastern US: Deep Structure Of a Complex Continental Plate. J. geophys. Res., 102, 8329-8348.

Barruol, G. and Souriau, A., 1995. Anisotropy beneath the Pyrenees range from teleseismic shear wave splitting. Geophys. Res. Lett., 22, 493-496.

Bonatti, E., 1996. Anomalous opening of the Equatorial Atlantic due to an equatorial mantle thermal minimum. Earth Planet. Sci. Lett., 143, 147160.

Burke, K.C., 1976. Development of graben associated with the initial ruptures of the Atlantic ocean. Tectonophysics, 36, 93-112.

Chang, H.K., Kowsmann, R.O.,

Figueiredo, A.M.F. and Bender, A.A., 1992. Tectonics and stratigraphy of the East Brazil Rift system: an overview. Tectonophysics, 213, 97-138.

Choukroune, P., 1992. Tectonic evolution of the Pyrenees. Ann. Rev. Earth Planet. Sci., 20, $143 \cdot 158$.

Cook, F.A., Albaugh, D.S., Brown, L.D.. Oliver, J.E. and Hatcher, R.D., 1979 Thin-skinned tectonics in the crystalline southern Appalachians; COCORP seismic-reflection profiling of the Blue Ridge and Piedmont. Geology, 7, 563-567.

Delvaux, D., Moeys, R., Stapel, G., Melnikov, A. and Ermikov, V., 1995. Paleostress reconstructions and geodynamics of the Baikal region, Central Asia. Part II: Paleozoic and Cenozoic prerift evolution. Tectonophysics, 252, 61-101.

Doser, D.I. and Yardwood, R., 1991. Strikeslip faulting in continental rifts: examples from Sabukia, East Africa (1928), and other regions. Tectonophysics, 197, 213-224.

Dunbar, J.A. and Sawyer, D.S., 1989. How preexisting weaknesses control the style of continental breakup. J. geophys. Res., 94, 7278-7292.

Durham, W.B. and Goetze, G., 1977. Plastic flow of oriented single crystals of olivine. 1. Mechanical data. J. geophys. Res., 82 , $57377 . .5753$.
Fairhead, J.D. and Binks, R.M., 1991 Differential opening of the Central and South Atlantic oceans and the opening of the West African rift system. Tectonophysics, 187, 191-203.

Hoffman, P.F., 1989. Precambrian geology and tectonic history of North America. In The Geology of North America a . An overview (A. W. Bally and A. R. Palmer. eds), pp. 447-512. The Geological Society of America, Boulder, CO.

Lebensohn, R.A. and Tomé, C.N., 1993. A self-consistent anisotropic approach for the simulation of plastic deformation and texture development of polycrystals: Application to zirconium alloys. Acta metall. mater., 41, 2611-2624.

Ma, Xingyuan and Wu, Daning, 1987 Cenozoic extensional tectonics in China. Tectonophysics, 133, 243-255.

Mainprice, D. and Silver, P.G., 1993. Interpretation of SKS-waves using samples from the subcontinental lithosphere, Phys. Earth Planet. Int. 78 , 257-280

Mercier, J.-C. and Nicolas, A., 1975 Textures and fabrics of upper mantle peridotites as illustrated by xenoliths from basalts. J. Petrol., 16, 454-487.

Nicolas, A. and Christensen. N.I., 1987. Formation of anisotropy in upper mantle peridotites - A review. In: Composition, Structure and Dynamics of the Lithosphere-Asthenosphere System ( $\mathrm{K}$ Fuchs and C. Froidevaux, eds), pp. 111123. American Geophysical Union. Washington, D.C.

Nicolas, A. and Poirier, J.P., 1976. Crystalline Plasticity and Solid State Flow in Metamor phic Rocks. Wiley. London, 444pp.

Ogawa, Y., Jones, A.G., Unsworth, M.J., Booker, J.R., Lu, X.Y., Craven. J., Roberts, B., Parmelee, J. and Farquharson, C., 1996. Deep electrical conductivity structures of the Appalachian Orogen in the southeastern US. Geophys. Res. Lett., 23, 1597-1600.

Olsen, K.H., Baldridge, W.S. and Callender, J.F., 1987. Rio Grande Rift: An overview. Tectonophysics, 143, 119-39.

Piqué, A. and Laville, E., 1996. The central Atlantic rifting: reactivation of Palaeozoic structures? J. Geodynamics, 21, 235-255.
Ring, U.. 1994. The influence of preexisting structure on the evolution of the Cenozoic Malawi rift (East African rift system). Tectonics, 13, 313-326.

Sénéchal, G.. Rondenay, S., Mareschal, M.. Guilbert, J. and Poupinet. G., 1996. Seismic and electrical anisotropies in the lithosphere across the Grenville Front. Canada. Geophys. Res. Lett.. 23. 2255... 2258.

Silver, P.G., 1996. Seismic anisotropy beneath the continents: Probing the depths of geology. Ann. Rev. Earth Planet Sci. 24, 385432.

Siricys, P.M., 1982. Anisotropie mecanique des roches. In: Mechanical Behavior of Anisotropic Solids (J. P. Boehler, ed.). pp 481-532. Martinus Nijhof, The Hague Centre National de la Recherche Scientifique, Paris.

Theunissen. K., Klerkx, J., Melnikov, A and Mruma. A.. 1996. Mechanisms of inheritance of rift faulting in the western branch of the East African Rift. Tanzania Tectonics, 15, 776-790.

Tommasi, A., Vauchez, A. and Daudré, B.. 1995. Initiation and propagation of shear zones in a heterogeneous continental lithosphere. J. geophys. Re's. 100, 22, 083 22,101 .

Ussami, N.. Sa, N.C. and Molina. E.C.. 1993. Gravity map of Brazil. 2, regional and residual isostatic anomalies and their corrclation with major tectonic provinces. J. geophis. Res., 98, $2199 \quad 2208$.

Vauchez, A. and Barruol, Ci.. 1996. Shear waves splitting in the Appalachians and the Pyrenees: Importance of the inherited tectonic fabric of the lithosphere. Phis. Earth Planet. Int. 95. 127-138.

Wilson, J.T.. 1966. Did the Atlantic close and then re-open?. Nature, 211, 676-681.

Worral, D.M. and Snelson, S. 1989. Evolution of the northern Gulf of Mexico. with emphasis on Cenozoic growth faulting and the role of salt. In: The Geology of North America--An overview (A. W. Bally and A. R. Palmer, eds), pp. 97-138. The Geological Society of America, Boulder, CO.

Zwart. H.J., 1986. The Variscan geology of the Pyrenees. Tectonophisics. 129.9-27.

Received 29 December 1996, revised version accepted 11 June 1997 